\title{
Strategic issues for Korean distribution companies' penetration of the Chinese market*
}

\author{
Chang-Yeoul Choi** and Joo-Young Lee***
}

\begin{abstract}
Since the declaration of reform and market opening from China in 1990, China has drawn much attention from the world thanks to its rapid economic growth and its emergence as the world's major consumer market and the center of the global economy. Moreover, it established the new trade order, making East Asia the center of the new trade trend as it becomes a manufactural and sales stronghold of multinational companies. The Chinese distribution market is expected to show a high growth rate by 2010 and it draws attention as a new business sector which can bring huge profits. However, advancement of the Chinese distribution industry now faces systemic problems and research on such problems is insufficient. Therefore, in this study we will conduct SWOT analysis based on previous studies on the Chinese distribution industry and use it as a ground to propose strategic solutions for development.
\end{abstract}

Keywords: global distribution, strategic frame, process of strategic planning, Chinese distribution network.

Submission Date: 11/30/2009

Revision Date: 12/11/2009

Acceptance Date: 12/11/2009

* This work was supported by the National Research Foundation of Korea Grant funded by the Korean Government (NRF-2008-005-J01602)

** First Author, Research Professor of Jungseok Research Institute of International Logistics and Trade, Inha University, Incheon, Korea. E-mail: ccy666@inha.ac.kr

${ }^{* * *}$ Corresponding Author, Research Professor of Jungseok Research Institute of International Logistics and Trade, Inha University, Incheon, Korea. E-mail: joo2636@inha.ac.kr 


\section{Introduction}

On November 18th, 2009, The Korea International Trade Association, Incheon Port Authority, Incheon Port Joint Distribution Company, Inc. and Tianjin Harvest International Trading Co., Ltd made a contract to establish a joint distribution center for distribution companies in Tianjin, China. This center is located within 10km from Xingang Harbours, Tanggu near Tianjin, China. It is planned to open within the first half of next year and will take on a role as a response logistics center cooperating with the Incheon joint distribution center. Then what is needed to succeed in the Chinese distribution market emerging as a starting point of global SCM?

According to analysis of the top 100 Chinese distribution companies' statuses conducted by The Korea International Trade Association in 2007, China became the largest SCM base as the entry of multinational distribution companies to the Chinese market has grown after the all-out opening of the distribution market in 2005. China, emerging as the center of global manufacturing and the biggest consumer market in the world, sees its distribution industry growing rapidly. According to the China Federation of Logistics and Purchasing, the total logistics cost of China marked 158.7 trillion Yuan from 2001 to 2005 and the average annual growth rate is $23 \%$, outnumbering the average annual growth rate of GDP, 9.5\% during the same period. This tendency is expected to continue by 2010 ,and it is expected that its distribution industry will grow by 16.7\% annually from 2006 to 2010 and that its national logistics cost will reach 90 trillion Yaun in 2010.

As the limit on shares which can be acquired by foreign companies is scraped since the all-out opening of the Chinese distribution market in December 2005, penetration and business expansion of multinational distribution companies have grown extensively. Beginning in late 2004, multinational distribution companies have established logistics facilities and service networks and then starting from 2005, they have fiercely invested in this market by expanding investment, establishing distribution centers, expanding subsidiaries and branches, and building national networks.

Also, the distribution service sector is growing steadily. According to data from Korea International Logistics Council of The Korea International Trade Association, multinational companies had penetrated mainly to the shipping and express logistics sector in the past, but since 2005, they have reached their hands into various sectors such as development of distribution real estate, provision of SCM solution and total logistics service, entry to the distribution tool market and human resource development. In 2008, the total exports and imports were 2 trillion 561.6 billion dollars, 17.8\% up compared to that of 2007 and the Chinese scale of global trade ranked third in the world, creating a huge trading amount.

But the problem is the fact that it is hard to find a Chinese distribution company which has global competitiveness although its market is rapidly expanding. Particularly upon the hosting of the 2008 Olympics, leading multinational distribution companies and Chinese 
distribution companies participated in a bid for the logistics service supplier for the 2008 Olympics. But, finally, the Organization Committee of the 2008 Olympics chose the U.S. firm, UPS and let it take a responsibility of managing the 2008 Olympic distribution center. Today, most distribution companies have grown on the base of planned distribution and logistics systems under planned economies. The Chinese distribution industry is still in its early stages and suffering from lack of long-term management systems, infrastructure, markets or services. Under this backdrop, we will examine strategic issues that Korean distribution companies should solve to penetrate into the Chinese distribution market where firms from advanced countries dominate.

\section{Changes in the Distribution Environment in China}

\subsection{Changes in distribution environment in China}

1) The entry of foreign firms into the Chinese market

The 4 world leading logistics companies (FedEx, UPS, TNT, DHL) entered into the Chinese market and fiercely vied in the market.

FedEx, putting focus on delivery service in China, has a service network in 220 cities in China and aims to expand its network to an additional 100 cities within 5 years. ${ }^{1}$ UPS established sales departments in 20 cities including Shenzhen, Qingdao, Amoy, Dongguan, Hangzhou, Shijiazhuang and Tianjin, and enhances its distribution chain service based on its stable business structure. ${ }^{2}$ TNT plans to increase its branches from 25 to 100 by 2010. Also, it expects to offer logistics, delivery and postal services to 1000 cities in China and hire employees in Chinese branches up to 30,000, and the size of its storage facilities stretches up to 3.25 million $\mathrm{m}^{2}{ }^{3}$ DHL still focuses on domestic delivery services. It is the only firm which acquired permission to deliver domestic parcels from the Chinese government and it holds $30 \%$ of Chinese market shares. ${ }^{4}$

In addition, Might \& Main has a competitive edge on ports and has done its best to expand its business especially in Shanghai, China. FESCO has the longest tradition among Russian shipping companies. Considering inactive marine routes between China and Russia, it has made an effort to take this as a chance. A French firm, FM Logistic proactively searches for a marine transportation partner.

\footnotetext{
1 http://www.fedex.com.cn

2 http://www.ups.com

$3 \mathrm{http://www.tnt.com}$

4 http://www.dhl-cn.com.cn
} 


\section{2) Growth of the Chinese distribution market after joining WTO}

After joining the WTO, China has seen rapid growth in the entry of foreign firms mainly to the manufacturing and distribution industries. As the entry of foreign firms into China increases, the scale of the Chinese distribution market grows fast. The demand for distribution is more than double the economic growth rate, and the total social logistics cost between 2001 and 2007 is 293 trillion yuan, showing 23.3\% in average annual growth rate. Also, the logistics demand coefficient of the Chinese unit GDP grew more than twofold from 1:1.4 in 1991 to 1.28 in 2007, showing that dependency on the distribution industry in the national economic growth increases. It shows that a demand for logistics gradually rises as the nation is industrialized. In 2007, the total social logistics cost of China was 75 trillion yuan, showing a $26.3 \%$ increase from the previous year, and it seems due to the rapid increase in industrial products and imports.

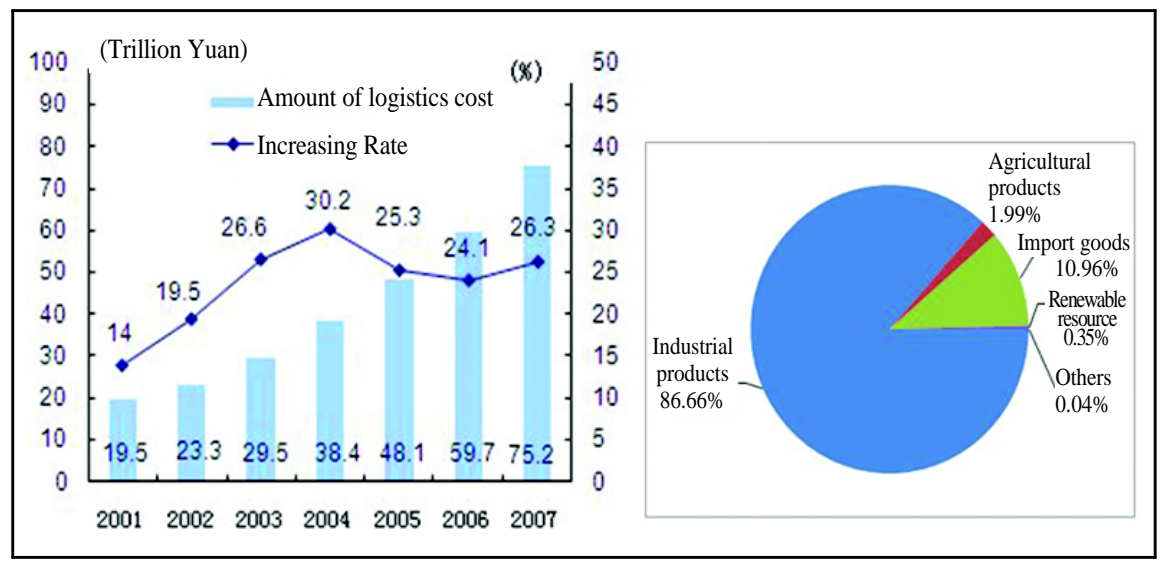

Source : Tao, Hua-Bin .2009. A Study on the Development Processes and Strategies of Chinese Logistic Companies. Graduate School of Paichai University. p.11.

Figure 1. The Chinese total social logistics cost and the component ratio

Since China is in the process of industrialization during the period of the 11th 5 year plan (2006 - 2010), it should bring changes in its industrial structure and economic growth plans. Therefore, the distribution industry as a productive service is expected to propel changes in those areas as it expands itself to the manufacturing, construction and trading sectors. 
3) The continuous increase in the national logistics cost

In 2007, the national logistics cost of China was 4500 billion Yuan, 18.2\% up from that of the previous year and the increase range went down by $4.7 \%$ from that of the previous year.

In 2007, the share of roads in total logistics was $63.2 \%$ showing that road transportation dominated domestic transportation in China. The share of the delivery cost in the national logistics cost marked $54.4 \%$, decreasing by $0.3 \%$ from that of the previous year, and it has the largest share. the storage cost was 1 trillion 419.3 billion yuan, up by $21.2 \%$ from that of the previous year and holding $32.9 \%$ of the national logistics cost. It clearly shows that the storage sector is growing significantly.

Table 1.

The ratio of logistics per GDP in China (\%)

\begin{tabular}{c|c|c|c|c}
\hline Year & $\begin{array}{c}\text { The logistics } \\
\text { cost }\end{array}$ & $\begin{array}{c}\text { The storage } \\
\text { cost }\end{array}$ & $\begin{array}{c}\text { The management } \\
\text { cost }\end{array}$ & $\begin{array}{c}\text { The total } \\
\text { logistics cost }\end{array}$ \\
\hline \hline 1991 & 13.3 & 7.5 & 3.2 & 24.0 \\
\hline 1992 & 12.7 & 7.2 & 3.1 & 23.0 \\
\hline 1993 & 12.8 & 6.6 & 3 & 22.4 \\
\hline 1994 & 11.6 & 6.8 & 3.1 & 21.4 \\
\hline 1995 & 10.6 & 7.3 & 3.2 & 21.2 \\
\hline 1996 & 10.7 & 7.2 & 3.2 & 21.1 \\
\hline 1997 & 10.4 & 7.4 & 3.3 & 21.1 \\
\hline 1998 & 10.3 & 6.7 & 3.2 & 20.2 \\
\hline 1999 & 10.6 & 6.0 & 3.3 & 19.9 \\
\hline 2000 & 10.1 & 6.0 & 3.2 & 19.4 \\
\hline 2001 & 9.9 & 5.9 & 3.1 & 18.8 \\
\hline 2002 & 10.0 & 6.1 & 2.9 & 18.8 \\
\hline 2003 & 10.4 & 5.9 & 2.6 & 18.9 \\
\hline 2004 & 10.6 & 5.6 & 2.6 & 18.8 \\
\hline 2005 & 10.2 & 5.8 & 2.5 & 18.6 \\
\hline 2006 & 10.0 & 5.9 & 2.4 & 18.3 \\
\hline 2007 & 10.2 & 5.9 & 2.3 & 18.4 \\
\hline$: 100$ & 2009 & 0.9 & & \\
\hline
\end{tabular}

Source : Tao, Hua-Bin. 2009. A Study on the Development Processes and Strategies of Chinese Logistic Companies. Graduate School of Paichai University. p.11. 
4) The increase in logistics outsourcing

Today, many Chinese manufacturers and retailers accelerate the adoption of outsourcing of logistics to cut costs. According to "the 6th survey on the demand and supply status in the Chinese distribution market" by the China Storage Association, more than 50\% of manufacturers and trading companies intend to cooperate with new distribution companies. According to the logistics market survey on manufacturers by the National Development Planning Commission in 2008, Outsourcing of sales distribution, and delivery and storage went up by 5 to $10 \%$ and 10 to $15 \%$, respectively (The report of Chinese logistics development 2007).

This trend affects foreign firms in China as well as domestic companies. One of the reasons behind the influence is that the distribution sector of a company can't afford the whole market as the consumer market of China grows.

The second reason is that the importance of logistics companies having knowledge of the situation of local markets increases as more and more foreign manufacturers in China buy parts and capital goods from Chinese firms.

The expansion of the logistics outsourcing market offers an opportunity to distribution companies in China-including multinational companies-and demands new services to those firms.

\subsection{A change in the competition structure among distribution companies in China}

1) The growth of private distribution firms

Chinese distribution companies can be classified in terms of their ownership and business features. The first category includes large state-owned distribution companies. They conduct conventional deliveries, storage and freight deliveries, and change their direction to 3rd parties or 4th parties. They include COSCO, CMST, China Shipping, China Post and they have a competitive edge holding a large amount of assets and the national networks through their good relations with the government.

The second category consists of newly emerging private logistics firms dealing with delivery, storage, roads and special distribution areas such as railroad freight delivery agencies. They include YUANCHENG Group, PGL, DTW, HOAU, and ZJS Express. They have cutting-edge knowledge and management technologies, but lack finance. Generally, they are small firms.

The third category consists of newly emerging professional logistics firms, state-owned or private manufacturers and the secondary distribution companies coming apart from existing retailers as those firms underwent restructuring. Those include Haier, CHUNLAN. They focus on particular areas or particular sectors and offer total distribution solutions. 
2) The growth of Chinese distribution companies

Since the 1999 government plan to foster the distribution industry, establishment of distribution companies has been accelerated. Around 38\% of the top 50 Chinese distribution firms were established after 2000. Only several state-owned firms dealt with logistics during the period of the planned economy (1978) and most distribution firms are new firms.

Long experience, nationwide networks, abundant assets and smooth use of finance may be key factors of the company growth. Two thirds of the top 50 distribution companies are owned by state-owned firms and their holdings. Especially, among the top 10 firms, 7 are state-owned and 2 have state-owned holdings companies. Therefore, the ratio of state-owned firms is huge.

Both the scales of registered and fixed assets of the top 50 Chinese distribution companies increased compared to those of 2005. Most firms had more than 50 million yuan in fixed assets and marked 500 million yuan in total sales in 2005. Services offered by the top 50 firms include delivery, storage, wrapping, clearance, distribution of IT systems, and the other distribution-related services.

3) The increase in strategic cooperation among companies

CNPL (中郵物流公司) built collection and delivery networks in the main 5 areas of China between 2001 and 2007 and linked delivery platforms dedicated to postal logistics including 31 provinces in China through post-exclusive rail transportation and highway transportation. At the same time, it established financial and information networks to enhance the quality of postal services and operational efficiency. COSCO Group reinforced the business chain by entering into partnership with COSTACO (中國外輪理貨總公司)

SITC Logistics was established through the merger of the distribution sector in SITC Maritime and New Times International Transport Service, the biggest private outbound airline forwarder in China in 2006. It made an expansion plan to distribution networks which can support $75 \%$ of China. Those cases clearly show that the increase in strategic partnership among distribution companies is a feature of recent Chinese distribution firms.

\section{4) Overseas expansion of distribution firms}

Thanks to adjustments in overseas trade strategies made by the Chinese government and overseas investment of manufacturers, overseas expansion of Chinese distribution companies has grown rapidly. Their motives to jump into the foreign markets are as follows:

The first motive is the sustainable growth of the trade scale. The trade scale of China is 1 trillion dollars and it shows more than $70 \%$ of trade dependency. The increase in the trade scale in China triggered demands for international logistics and it became a motive for 
domestic logistics firms in China.

The second is the increase in foreign investment of Chinese firms. Direct investment of China to foreign markets is about 1 trillion dollars and wholesalers, retailers and manufacturers account for approximately $20 \%$ and $10 \%$ of it, respectively. Generally, manufacturers have invested in the sectors of communications devices, calculators, other electronic appliances, textile manufacturing, transportation equipment, pharmaceuticals, metals, and electric machines and devices. Their overseas expansion has caused international logistics demands and it requires the entry of other domestic firms, too.

The third motive is the enhancement of Chinese distribution firms' competitiveness. Amid the continuous and stable economic growth of China, the scale of Chinese distribution companies is expanding and domestic firms, usually state-owned firms are growing into total distribution companies focusing on shipping and logistics as they merges those two sectors.

The fourth is strategic restructuring of Chinese logistics firms. As global distribution firms penetrate into the Chinese market, domestic firms feel pressured. Therefore, globalization is considered as an active defense measure against global firms to boost their competitiveness.

The final motive is the policy to promote foreign investment due to the expansion of foreign reserves in China. Receiving support from the government, Chinese firms actively invested in overseas markets and logistics investment overseas amounted to 7 billion dollars in 2005 , accounting for $12.4 \%$ of the total investment.

\section{Literature review of distribution advancement in China}

\subsection{Literature review of the distribution industry}

The Chinese logistics industry has developed from the ground of the distribution and logistics systems of the previous conventionally planned economy. It is still in its early stages and suffering from lack of long-term management systems, infrastructure, markets or services. However, it is growing fast as the entry of global distribution companies and policies of the government to support the industry propels economic globalization and the opening of the information era. ${ }^{5}$

Shawn P. Daly and Lindsay N. Cui (2003) ${ }^{6}$ analyzed the current status of China's electronic trade and electronic logistics, and drew problems of the process of electronic logistics' development by interviewing the government and companies. Also, they offered

\footnotetext{
5 Won, Dong-Wook and Cho, Gi-young. 2006. The Development of Logistics in China and the Strategy of Korean Logistics Enterprises entering China Market. The Korea Transport Institute. p. 8.

6 Daly, Shawn P. and Cui, Lindsay X. 2003. E-logistics in China: basic problems concerns and intractable solutions. Industrial Marketing Management. Vol.32. pp.235-242.
} 
measures for development and solutions to the problems.

John Kerr (2007) ${ }^{7}$ noted that the bottle-neck situation during the development of the Chinese distribution industry can be an obstacle to rapid economic growth and argued that the airline industry will advance despite the poor distribution infrastructure.

William Hoffman (2005) ${ }^{8}$ offered measures such as the establishment of infrastructure, IT systems and management of supply chain for the development of modern Chinese logistics.

S. B. Hwang (2008) ${ }^{9}$ reviewed the theoretical background of logistics through existing research at home and abroad and noted problems of the Chinese distribution industry and proposed solutions by comparing it with that of advanced countries and analyzing the current situation.

S. W. Lee and H. M. Kim (2007) ${ }^{10}$ studied the key factors which trigger future changes in the market from the prospect of distribution companies, focusing on the changes in business policies and proposed predictable changes in the market and responsive measures of the Korean government and distribution companies.

J. Lee (2007) 11 offered measures such as the establishment of globalization systems of distribution information networks, reflection of rationalization and efficiency in making electronic commerce policies. Consideration of electronic commerce environment in making logistics policies, adoption and promotion of integrated logistics environments and measures to boost the efficiency of delivery to respond to the distribution information networks of China in this era of e-commerce.

C. Y. Choi (2007) ${ }^{12}$ studied the influence of SCM strategic integration of Chinese firms to achievement of distribution firms based on achievement of SCM strategic integration of Chinese distribution firms and changes in the logistics environment in China.

\subsection{Literature review of the Chinese distribution companies' competitiveness}

To have a competitive edge in terms of cost, global firms make it their strategy to produce in mass and export to the global markets at low cost. So they are located in areas where they can produce goods at the lowest cost and make standardized goods under the

${ }^{7}$ Kerr, John 2007. A Road to China's Logistics Landscape. Logistics Management. Vol.46. No.1. pp.1-4.

8 Hoffman, William 2005. China's Logistics Lessons. Traffic World. Vol.269. No.40. p.21.

9 Huang, Xue Bin. 2008. A Study on the Present Situation and Development Strategy of Logistics Industry in China. Graduate School of Pai Chai University.

10 Lee, Sung Woo and Jin, Hong Mei. 2007. Impact of China Logistics Market Based on Changing of Enterprise Policy in China. Research Activities. Vol.25 No.1. pp.67-96.

$11 \mathrm{Li}$, Jing. 2007. A study on a plan for activation of Chinese logistics with the development of E-commerce. Master Deggree of Sungkyunkwan University.

12 Choi, Chang- Yeoul. 2007. An Empirical Study on the SCM strategy and Business Performance of China Logistic Company. The e-Business Study. Vol.8 No.4. Global e-Business Association, pp.95-117. 
assumption that consumer demands are the same. Such global logistics are done between borders unlike domestic logistics. Therefore, it is more intricate in terms of trade procedures, clearance and diversification of delivery methods. Generally, their delivery distance is long and they tend to ship a large amount of freight. So, they face environmental restrictions. In addition, the cost scale of global logistics is huge and their strategic value gets greater as the globalization or multi-nationalization advances for exporters. If local manufacturing grows due to direct overseas investment, the importance of global logistics goes up. Therefore, many researchers have studied to promote the globalization of distribution companies and enhance global competitiveness.

John King (1997) ${ }^{13}$ specified the process of globalization of distribution companies and offered the distribution status of the conventional marine transportation industry and problems to be solved to develop global logistics by considering the importance of a supply chain.

Kennth Zantow and Qing Wang (2006) ${ }^{14}$ pointed out development status and limitations of the 3rd party distribution firms in mainland China and offered the direction of development and strategies.

H. M. Kim (2007) 15 made an evaluation system to solve the growing problems of logistics due to the rapid growth of China which lead to its global economic advancement and a port competitiveness index by using the AHP method to analyze the competitiveness of Chinese port logistics from the view of Korea.

M. H. Lee and J. Y. Lee (2007) ${ }^{16}$ proposed measures to strengthen the competitiveness of Chinese distribution firms by focusing on firms where their main business is marked as logistics among listed enterprises after considering it hard to obtain detailed management data from Chinese firms.

M. Y. Jang (2007) ${ }^{17}$ studied the change and the status of the distribution industry per city near the Yangtze River Delta, became familiar with the consumer market of the Yangtze River Delta in China and offered the penetration status of Korean and foreign distribution companies into the Yangtze River Delta distribution industry and strategies to boost the competitiveness of Korean firms.

13 King, John 1997. Globalization of logistics management present status and prospects. Maritime Policy \& Management. Vol.24. No.4. pp.381-387.

14 Zantow, Kenneth and Wang, Qiang. 2006. Strategic postures of third-party logistics providers in mainland China. International Journal of Physical Distribution \& Logistics Management. Vol.36. No.10. pp.793-819.

15 Jin, Xiao Mei. 2007. An Analysis of Competitiveness on Chinese Logistics Industry. Master Degree of Kyungnam University.

16 Lee, Myung Hun and Lee, Jun Yeop. 2007. A Business Analysis and Competitiveness for Chinese Logistic Companies. Journal of Korean National Economy. Vol.25 No.3. Korea Economics and Business Association. pp.133-154.

17 Zhang, Mei Youon. 2007. Strategies of the korean distribution companies into china. Master Degree of Sungkyunkwan University. 
M. H. Chae (2007) ${ }^{18}$ analyzed the status of the local delivery industry in China in consideration of the rise in a demand of delivery, reviewed measures to boost competitiveness of Chinese delivery firms among fierce competition, and proposed optimal measures. To do that, she showed the market survey and analysis of the Chinese delivery industry, competitive analysis through case studies and measures to enhance competitiveness.

黃广本 (2008)19 offered government policies and measures for private firms to raise global competitiveness to solve problems he offered from the globalization of Chinese private firms.

\subsection{SWOT analysis on the Chinese logistics environment}

At a time when the Chinese economy is growing rapidly and its socialist market economy is settling (and while the liberalization of global trade supported by the WTO and FTA is accelerated), there have been tremendous changes in both the internal and external environment of the Chinese logistics industry. Such changes have offered not only a good opportunity for the development of the Chinese logistics industry but also a severe challenge to it. In this research, we conducted the following SWOT analysis on the Chinese logistics environment by analyzing contents about the Chinese logistics environment from 249 theses from the Korean Education \& Research Information Service by the word, 'Chinese logistics' between August 3rd 2009 and November 17th 2009. The results show that China has strength in the area of the increased logistics demand. But it has a weaknesses in infrastructure and opportunities of multinational distribution companies which entered into the Chinese distribution industry. It also has a threat that its conventional domestic distribution firms are dwindling.

18 Chae, Mi Hwa. 2007. Strategies for Competitiveness and the Management Character of the Courier Service Firm of China. The Master Degree of Sungkyunkwan University.

19 黃广本. 2008. 我國民營企業國際化問題與對策. 汇西科技師范學院學報.第6期. pp.18-20. 
Table 2.

SWOT analysis on the Chinese logistics environment

\begin{tabular}{|l|}
\hline Strength \\
\hline • Full-support from the Chinese government \\
• Investment to the logistics sector \\
- The increase in a logistics demand \\
- The advancement of the 3rd party logistics \\
- Establishment of distribution information \\
networks \\
- Distribution rationalization \\
\hline
\end{tabular}

\begin{tabular}{|l|}
\hline Opportunity \\
\hline • Fierce competition in the Chinese \\
distribution market \\
- Diversification of the logistics development \\
environment \\
- Rapid development of the distribution \\
industry \\
- The hike in a logistics demand due to \\
advancement of new industries \\
- Advancement of scientific technologies \\
related to logistics
\end{tabular}

\section{Weakness}

- Lack of basic infrastructure

- Inefficient systems of distribution management

- Incomplete logistics laws and regulations

- Lack of the human resource system

\section{Threat}

- The increase in competition with multinational distribution companies

- Lack of talented manpower in China

- The decrease in the market share

\section{Strategies for the entry of Korean distribution companies}

\subsection{Competition strategy}

As competition among existing distribution companies, their subsidiaries, joint distribution firms and wholesale deliverers is facilitated, potential distribution firms can find diversified alternatives to boost their competitiveness. Therefore, we offer the following competition strategies for them to enhance their competitiveness.

First, by taking the price advantage strategy, one can reinforce its price advantage based on the low cost and exclude high cost services and offer services a slow price by reflecting 
the effect of economy of scale. One should focus on securing more demands by doing so.

Second, by adopting service differentiation strategies, one has to vie in high-quality service by developing logistics services with high added value.

Third, one should offer distribution services which specialize in terms of sales items, types of services, characteristics of customers and regions by taking the focus strategy.

To use competitive strategies successfully, it is important to conduct service development and operation from the view of customers and change the management structure to reflect those.

\subsection{Structural Strategy}

Structural management of manufacturing factors is important to boost the logistics competitiveness of distribution companies. In other words, it is important to secure measures to enhance the efficiency of a company. In this research, we offer the following structural strategies based on the existing literature:

The first is a strategy of collaboration, cooperation with related businesses and large scale through strategic partnership as a strategy of scale or specialization. To do that, one should make up for or secure management resources.

The second is a strategy of service diversification and expansion. A company should become an agency which can do any business related to logistics. Therefore, it should expand its range of services to the whole integrated logistics service.

The third is a collaboration strategy. A company has to prepare for competition with large distribution firms by establishing nationwide networks through strategic partnership with small and medium sized distribution firms.

Considering that most manufacturers sell goods both at home and abroad, the Chinese distribution firms should secure ability to offer integrated logistics services. Most American distribution firms offer both domestic and overseas logistics services. To offer such services, a huge amount of investment is needed. Therefore, companies should find measures to logistics services within the supply chain by establishing a logistics network through strategic partnership among distribution firms and related businesses (a consulting firm, IT firms) having different ranges of service.

\subsection{Reinforcement of government support}

Under the current system of China, it is hard for distribution companies to manage comprehensive logistics collectively. Still in China, there is no regulation to control logistics comprehensively and there are many government bodies in charge of logistics. To conduct a collective and complex delivery by linking domestic and overseas logistics, a distribution 
firm has to undergo some registration and permission procedures under several different laws. So the amendment and improvement of the current logistics law and system are needed to achieve high efficiency in logistics by promoting the Chinese distribution industry.

Furthermore, a company should become larger in some degrees to have competitiveness. It is incorrect to say that the bigger the firm is, the more competent it is. But most of the Chinese firms are too small to acquire professional knowledge and technology. Therefore, emergence of big distribution companies through M\&A among businesses and liberal competition is needed. So, the government has to support firms institutionally to induce M\&A through free competition.

Also, foreign distribution firms can be a threat to the domestic market in the short term. But in the long term, they are a key factor for the development of the Chinese logistics industry. They ease the problem due to lack of supply in the domestic market and domestic firms can learn advanced IT for logistics and operational systems by entering into partnership with advanced foreign companies. Therefore, the government should keep incentives for foreign firms to promote entry and adjust a range of regulations.

\subsection{Adoption of information technology}

Distribution companies have to have access to sales and manufacturing information of customers to control distribution of goods depending on the change in information. If a customer fails to offer appropriate information in a timely manner, distribution firms can not distribute products on time. So it will trigger the increment in stocks and the deterioration of the service level.

In this respect, the level of advanced logistics information technology adoption is significantly low. At a time when most customers have adopted and operated IT systems, it is essential to adopt advanced IT and IT systems for the advancement of distribution firms. So, domestic firms have to establish reasonable systems and adopt new IT such as logistics EDI, POS GPS, and TRS to respond to the changes in the market promptly.

\subsection{Preparation for the 4th party logistics}

The 4th party logistics are professional distribution firms which have integrated merits of outsourcing and insourcing and they are needed to get the maximum achievement of management. However, the 4th and the 3rd party distribution companies are not different. If the 3rd party distribution firm has an ability to do advanced consulting or manage the whole SCM such as reestablishment of logistics, it is called the 4th party distribution firm. The 4th party logistics focus on the capacity of logistics outsourcing to promote the improvement of customer service, financial influence and simplification of labor problems. In other words, 
the 4th party logistics can promote the value of shareholders by increasing profits, managing operational costs efficiently, and reducing operational assets and fixed assets. Therefore, it is definitely necessary to prepare for the 4th party logistics for the future.

\section{Conclusion}

China is emerging as a consumer market for the world from the factory of the world and the entry of multinational manufacturers and distribution companies to China is facilitated. To achieve efficiency in management, a huge amount of human and financial recourses are concentrated to the Chinese distribution market. The authorities recognize it as the key industry for economic growth and channel a huge amount of money to secure infrastructure and systems. Also they deregulate for foreign investors. But, the Chinese distribution firms have inefficient systems due to limits of service and lack of professionals, IT and poor infrastructure. Moreover, the Chinese distribution industry is lagging behind, inefficiency, abnormally large logistics of customers and government policies affect adversely.

In this research, we considered alternatives to tackle the issues. Such alternatives will become incentives for Korean firms to penetrate into the Chinese market. In conclusion, domestic logistics firms should raise their abilities of logistics consulting to succeed within the Chinese market and adopt quality logistics information systems to respond rapidly to the changes in IT. Also, they have to establish competition and structural strategies to enter the Chinese market. Of course, there are many problems to solve. The Chinese logistics environment is not that mature to expect spontaneous development. Therefore, the intervention and role of the government are essential.

In this research, we conducted SWOT analysis based on the existing literature and offered strategic alternatives by analyzing the strengths and weakness of the Chinese distribution industry based on the analysis. META analysis can be more accurate and there are various methods, such as the efficiency analysis of the Chinese market. But we used restrictive methods since the aim of this research is to propose strategic alternatives.

This study is also based on the research on the Chinese distribution industry (market) conducted in Korea. In further studies, we will include a detailed analysis of Chinese research.

\section{Reference}

Chae, Mi Hwa. 2007. Strategies for Competitiveness and the Management Character of the Courier Service Firm of China. The Master Degree of Sungkyunkwan University. Choi, Chang-Yeoul. 2007. An Empirical Study on the SCM strategy and Business 
Performance of China Logistic Company. The e-Business Study. Vol.8 No.4. Global e-Business Association. pp.95-117.

Daly, Shawn P. and Cui, Lindsay X. 2003. E-logistics in China: basic problems concerns and intractable solutions. Industrial Marketing Management. Vol.32. pp.235-242.

Lee, Myung Hun and Lee, Jun Yeop. 2007. A Business Analysis and Competitiveness for Chinese Logistic Companies. Journal of Korean National Economy. Vol.25 No.3. Korea Economics and Business Association. pp.133-154.

Lee, Sung Woo and Jin, Hong Mei. 2007. Impact of China Logistics Market Based on Changing of Enterprise Policy in China. Research Activities. Vol.25 No.1. pp.67-96.

Li, Jing. 2007. A study on a plan for activation of Chinese logistics with the development of E-commerce. Master Degree of Sungkyunkwan University.

Hoffman, William. 2005. China's Logistics Lessons. Traffic World. Vol.269 No.40. p.21.

Kerr, John. 2007. A Road to China's Logistics Landscape. Logistics Management. Vol.46 No.1. pp.1-4.

King, John. 1997. Globalization of logistics management present status and prospects. Maritime Policy \& Management. Vol.24 No.4. pp.381-387.

Won, Dong-Wook and Cho, Gi-young. 2006. The Development of Logistics in China and the Strategy of Korean Logistics Enterprises entering China Market. The Korea Transport Institute. p. 8.

Jin, Xiao Mei. 2007. An Analysis of Competitiveness on Chinese Logistics Industry. Master Degree of Kyungnam University.

Huang, Xue Bin. 2008. A Study on the Present Situation and Development Strategy of Logistics Industry in China. Graduate School of Pai Chai University.

Zantow, Kenneth and Wang, Qiang. 2006. Strategic postures of third-party logistics providers in mainland China. International Journal of Physical Distribution \& Logistics Management. Vol.36 No.10. pp.793-819.

Zhang, Mei Youon. 2007. A study on the entrance strategies of the Korean distribution companies into China. Master Degree of Sungkyunkwan University.

黃广本. 2008. 我國民營企業國際化:問題與對策. 江西科技師范學院學報. 第6期. pp.18-20.

中華人民共和國 商務部(http://www.mofcom.gov.cn/)

2008年 中國對外貿易情況. 2009.

http://www.fedex.com.cn

http://www.ups.com

http://www.tnt.com

http://www.dhl-cn.com.cn 